\title{
Caudal brain infarctions in a kitten - case report
}

\section{Infartos em região encefálica caudal em gata filhote - relato de caso}

\author{
Lucas Alécio Gomes ${ }^{1 *}$; Giórgio Queiroz Pereira ${ }^{2}$; \\ Vítor Solano de $\mathrm{Melo}^{3}$; Selwyn Arlington Headley ${ }^{4}$
}

\begin{abstract}
Stroke is uncommon in animals compared with humans because of the lower incidence of atherosclerosis and primary hypertension. However with advanced imaging, vascular disease is being recognized with increasing frequency in veterinary medicine. Cerebrovascular disease can be subdivided into infarction and hemorrhage, although the two categories overlap in the case of hemorrhagic infarcts. The aim of this article is to report the neurological manifestations associated with stroke (infarctions) in at two-month old, domestic shorthair cat. Neurological evaluation revealed head tilt, tetraparesis, proprioceptive deficits in all four limbs, and decreased pupillary light reflex. Further, manifestations of neurological dysfunctions were acute and progressive. At the necropsy, grossly there were hemorrhage and necrosis at mid-brain and cerebellum. Histopathology confirmed liquefactive necrosis at the mid-brain and cerebellum. The neurological manifestations associated with the pathological findings are suggestive of an anoxic infarction probably due to vascular occlusion.
\end{abstract}

Key words: Feline disease, neurology, infarction, multifocal syndrome, histopathology

\section{Resumo}

Em animais é baixa a incidência de arterosclerose e hipertensão primária. Devido a tal característica, infarto cerebral é incomum nos mesmos. Entretanto, com o avanço das modalidades de imagem, doença vascular está sendo reconhecida com maior frequência na medicina veterinária. Doença cerebrovascular pode ser subdividida em infarto e hemorragia, embora as duas categorias se interponham no caso de infartos hemorrágicos. Assim sendo, o objetivo deste artigo é descrever as manifestações neurológicas associadas a acidente vascular (infartos) em uma gata de dois meses de idade, sem raça definida e domiciliada. $\mathrm{Na}$ avaliação neurológica observou-se inclinação de cabeça, tetraparesia, déficits proprioceptivos nos quatro membros e diminuição do reflexo pupilar a luz. Além disso, os problemas neurológicos foram agudos e progressivos. Na necropsia macroscopicamente detectou-se hemorragia e necrose no mesencéfalo e cerebelo. No exame histopatológico confirmou-se a presença de necrose liquefativa no mesencéfalo e cerebelo. Os sinais neurológicos associados com os achados patológicos são sugestivos de infarto levando a anóxia provavelmente devido à oclusão vascular.

Palavras-chave: Gato, neurologia, infarto, síndrome multifocal, histopatologia

\footnotetext{
${ }^{1}$ Prof. Adjunto, Dept ${ }^{\circ}$ de Clínicas Veterinárias, Universidade Estadual de Londrina, UEL, Rodovia Celso Garcia Cid, PR 445, Km 380, Campus Universitário, CEP: 86051-980, Londrina, PR. E-mail: lucasalecio@gmail.com

${ }^{2}$ Médico Veterinário Autônomo, Clínica Veterinária Saúde Animal, Balneário Camboriú, SC. E-mail: giorgioqueiroz@yahoo.com.br

${ }^{3}$ Médico Veterinário Autônomo, Ex-Residente do Setor de Anatomia Patológica, Dept ${ }^{\circ}$ de Medicina Veterinária Preventiva, UEL, Londrina, PR. E-mail: vitor_solano@yahoo.com.br

${ }^{4}$ Prof. Pesquisador Universidade do Norte Paranaense, UNOPAR, Campus Arapongas, Arapongas, PR. Pós-Dotorando do Programa de Pós-Graduação em Ciência Animal, Dept ${ }^{\circ}$ de Medicina Veterinária Preventiva, UEL, Londrina, PR. E-mail: headleysa@gmail. com

* Author for correspondence
} 


\section{Introduction}

There has been some confusion within the veterinary literature relative to the usage of the terms cerebrovascular disease, cerebrovascular accident, and stroke (GAROSI; PLATT, 2009). Infarct, ischemic encephalopathy, stroke, and cerebrovascular accidents are synonyms (DEWEY, 2011). The term "cerebrovascular disease" is defined as any abnormality of the brain resulting from a pathologic process compromising its blood supply. Pathologic processes of blood vessels include occlusion of the vascular lumen by a thrombus or embolus, rupture of the wall of a blood vessel, lesion or altered permeability of the vascular wall, and increased viscosity or other changes in the quality of the blood (GAROSI, 2012; GAROSI, 2010; GAROSI; PLATT, 2009). Stroke is uncommon in animals compared with humans because of the lower incidence of atherosclerosis and primary hypertension (O'BRIEN; COATES, 2010). However, with advanced imaging, vascular disease is being recognized with increasing frequency in veterinary medicine (O'BRIEN; COATES, 2010). Cerebrovascular disease can be subdivided into infarction and hemorrhage, although the two categories overlap in the case of hemorrhagic infarcts (GAROSI, 2010; GAROSI; McCONNELL, 2005; O'BRIEN; COATES, 2010). Possible diseases that can cause thrombosis are: hypothyroidism (atherosclerosis) and idiopathic hyperlipidemia. Embolism can be induced by sepsis, cardiac disease, neoplasia or coagulopathy. Hypertension is another common cause, which in the majority of the cases is secondary to chronic renal failure and hyperadrenocorticism (GAROSI, 2010; GAROSI; PLATT, 2009; GAROSI; McCONNELL, 2005; GAROSI et. al., 2005; O'BRIEN; COATES, 2010). Other conditions include diabetes mellitus, hyperthyroidism, atherosclerosis associated with hypothyroidism, aberrant parasite migration, parasitic emboli, hepatic failure, phaeochromocytoma, and infectious diseases (GAROSI, 2012; CARLSON，2011; DEWEY,
2011). Feline ischemic encephalopathy has been linked to intracranial migration of Cuterebra larvae (DEWEY, 2011; WILLIAMS; SUMMERS; De LAHUNTA, 1998).

Once the diagnosis of stroke is made, any potential underlying disease is identified and treated accordingly. The general aim is to provide supportive care, maintain adequate tissue oxygenation, and manage neurologic and nonneurologic complications (GAROSI, 2012). Treatment of an ischemic stroke revolves only with supportive care, and evolves principles such as monitoring and correcting basic physiologic variables (e.g., oxygen level, fluid balance, blood pressure, body temperature). With supportive care, recovery usually occurs within several weeks in most cases (GAROSI, 2012; GAROSI, 2010; GAROSI; PLATT, 2009).

The objective of this article is to describe a case of stroke (infarction) in a kitten. This condition is not expected and is not common in the respective age-group, which highlights the importance of this case.

\section{Case Report}

A two-month-old, $0.3 \mathrm{~kg}$ domestic shorthair cat was admitted to the Veterinary Teaching Hospital, Universidade Estadual de Londrina, Paraná, Brazil, after two days of depression, and presenting mild respiratory distress. The owner reported that the animal had contact with two adult Rottweilers, which perhaps could have attacked the kitten. The clinical evaluation revealed: dehydration (7\%), depression, hypothermia, and decubitus. According to the owner, before the symptoms the cat was normal. The initial neurological examination was difficult to perform due to the size and weakness of the kitten. However, it was possible to identify head tilt, body turning to the right side, tetraparesis, proprioceptive deficits in all four limbs, and decreased pupillary light reflex (PLR). The proprioceptive deficit was difficult to confirm because of body weakness, since 
the animal was not eating normally. The symptoms were consistent with a midbrain syndrome and vestibular disease, which can be classified as a multifocal syndrome.

Values of complete blood count (CBC), urinalysis, urine culture and blood chemistry were within the normal limits. Attempts to verify blood pressure were frustrating due to the small stature of the kitten. According to the owner, the initial hypothesis was traumatism caused by dogs, thus cerebrospinal fluid (CSF) was not collected in this case.

Treatment was directed against brain damage and/or encephalitis: fluid therapy (Ringer lactate) intravenously (IV); 20\% Manitol $^{\circledR}-1 \mathrm{~g} / \mathrm{kg} / \mathrm{IV}$ / SID; Methylprednisolone $30 \mathrm{mg} / \mathrm{kg} / \mathrm{IV} / \mathrm{SID}$; and heating. There was improvement in the first three days of treatment after which Manitol ${ }^{\circledR}$ and Methylpredniosolone were withdrawn. From the fourth day, therapy was initiated with prednisolone $2 \mathrm{mg} / \mathrm{kg}$ orally. The clinical improvement was stable, the animal returned to feeding, but the head tilt depression and ataxia in all four limbs remained. However, the cat remained on station sometimes. Ten days after admission, the animal suddenly developed coma, bradycardia, hypothermia, dyspnea, and therapy with Manitol ${ }^{\circledR}$ and Methylprednisolone was reinstated. The kitten improved within twenty-four hours and returned to feeding, but five days thereafter, presented apathy, anisocoria and hypothermia without any improvement, despite adequate therapy. The kitten died spontaneously the following day, and a routine necropsy performed soon after.

Gross lesions were restricted to the midbrain and cerebellum (Figure. 1) and were characterized as hemorrhage and tissue softening (necrosis). Histologically there were a severe liquefactive necrosis with the formatting of cystic cavity (infarction) in the midbrain (Figure 2) and in the cerebellum there were severe hemorrhage with loss of neuroparenchymal tissue.

Figure 1. Encephalon, kitten, sagittal section; there are areas of hemorrhage with cavitation necrosis at the midbrain (black arrow) and cerebellum (white arrow).

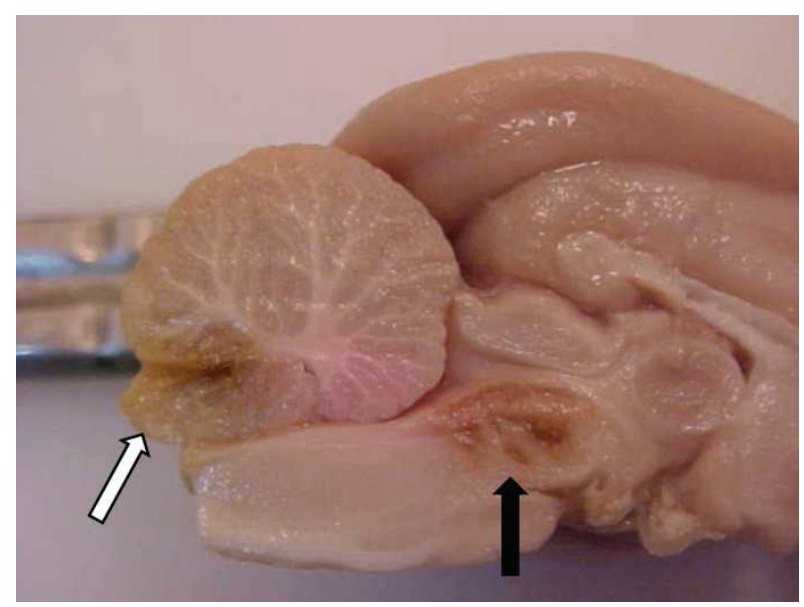

Source: Elaboration of the authors. 
Figure 2. Midbrain, kitten; there is a severe liquefactive necrosis with the formatting of cystic cavity.

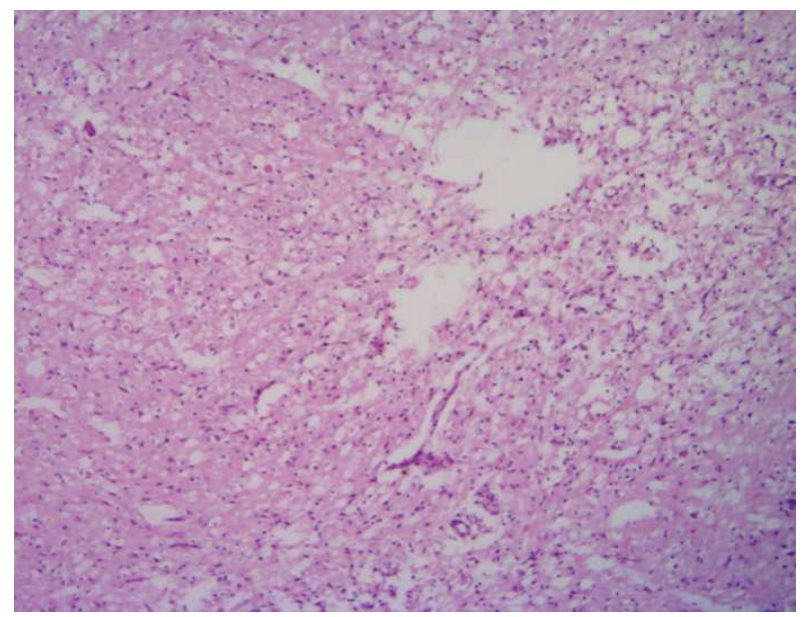

Source: Elaboration of the authors.

\section{Discussion and Conclusions}

Neurological problems that occur suddenly (with or without progression) are usually associated with trauma, vascular lesions and sometimes intoxication (DEWEY, 2011; GAROSI, 2010; O'BRIEN; COATES, 2010). Vascular encephalopathy includes the follow differential diagnosis: inflammatory/ infectious, trauma, metabolic, head trauma, brain neoplasm and neurotoxicity (GAROSI, 2012; DEWEY, 2011; GAROSI, 2010; O'BRIEN; COATES, 2010). These differentials are appropriated in this case because depending on the severity of the disease signs such as depression, head tilt and body turning, stupor and coma, might occur, and these signs manifestations were observed in this kitten. However, vascular disease was not included in the first list of differentials diagnosis in this case because the age (two months) of the cat. Although the owner had reported that trauma was not witnessed, it was not entirely ruled out, because the kitten used to live with two adult dogs. Alternatively, the condition of the animal deteriorated, which is not expected in the most cases of head trauma. Other important differential diagnoses for kittens with signs of brain disease are infectious diseases, congenital defects and Cuterebra larvae (GAROSI, 2012; DEWEY, 2011; GAROSI, 2010; O'BRIEN;
COATES, 2010). However, the last disease was never described in Brazil. There were no evidence of gross lesions consistent with congenital problems at the necropsy and despite of this, it is important to emphasize that according to the owner, the animal was normal until the problems appeared. Considering these alternatives, the possibility of trauma occurring remains as part of the differential diagnoses; this resulted in the non-collected CSF tap. The decreasing of pupillary light reflex (PRL) is in concordance with Cherubini et al. (2007) where a cat presented cerebellar infarction and consequently absence of PLR. The main limitation in this case was the impossibility to use MRI or CT scans to assist in the early diagnosis, because such equipment's is not available at the Veterinary Teaching Hospital, and the owner indicated that it would not have been possible to send the animal to a Center where CT scans are available.

The brainstem is the major center to maintain an individual awake; lesion to the brainstem might result in depression, stupor or coma (De LAHUNTA, 2009), and as the progression of the lesion progresses, death will occur, as was seen in this case. The vestibular symptoms are justified by the cerebellar lesion (probably the floculonodular lobe was affected - paradoxal vestibular syndrome) 
or a lesion in the vestibular nucleus on the brainstem, although the last one were not evident macroscopically.

Cherubini et al. (2007) reported a case of a 10 -year-old neutered female domestic shorthair cat that was maintained indoor only, that developed overnight peracute non-ambulatory tetraparesis. The neurological examination revealed normal mental status with decerebellate posture and nonambulatory tetraparesis. The neuroanatomical localization was consistent with a peracute cerebello-medullary lesion with involvement of the cerebellar nuclei and brainstem. Based on the MRI results, history and neurological examination a presumptive diagnosis of rostral cerebellar and multiple lacunar brain infarctions were made. The owner elected for euthanasia. In this case the acute onset and rapid progression of the neurological syndrome associated to the pathological alterations are high suggestive hypoxic infarctions due to vascular occlusion; however, diagnostic imagining would have been important to elucidate the actual causes of the brain lesions.

Altay et al. (2011) have described in a study of 16 cats with nontraumatic and nonneoplastic cerebrovascular disease confirmed by histology. It was suggested that the unique arterial supply in cats might influence the incidence of cerebrovascular accidents in this species. Of the 16 cats reviewed, 7 had ischemic infarctions, 5 hemorrhagic infarctions, and 4 were diagnosed with intracranial hemorrhage. The median age was 8 years and 9.5 years in cats with infarctions and intracranial hemorrhages, respectively. Clinical signs were severe, acute, consistent with the localization of the cerebrovascular lesion, and influenced by underlying pathology. Cerebrospinal fluid analysis and computed tomography scans were available for two cats. In conclusion, the clinical picture is influenced by the type of cerebrovascular disease, the localization of the intracranial lesions, and any underlying pathology. In our case, the kitten was 2-month-old, which is in discordance with Altay et al. (2011) findings; these authors reported stroke only in older cats.

Based on the author's knowledge, this is the first published report of a kitten with brainstem and cerebellar stroke. In conclusion it is important to consider that young animals can present stroke which might be acute and progressive.

\section{References}

ALTAY, U. M.; SKERRITT, G. C.; HILBE, M.; EHRENSPERGER, F.; STEFFEN, F. Feline cerebrovascular disease: clinical and pathologic findings in 16 cats. Journal of the American Animal Hospital Association, v. 47, n. 2, p. 89-97, 2011.

CARLSON, K. J. Feline infections peritonitis. In: CÔTÉ, E. Clinical veterinary advisor. $2^{\text {nd }}$ ed. St. Louis, Missouri: Elsevier Mosby, 2011, p. 383-385.

CHERUBINI, G. B.; RUSBRIDGE, C.; SINGH, B. P.; SCHOENIGER, S.; MAHONEY, P. Rostral cerebellar arterial infarct in two cats. Journal of Feline Medicine and Surgery, v. 9, n. 3, p. 246-253, 2007.

De LAHUNTA, A. Diencephalon. In: De LAHUNTA, A.; GLASS, E. Veterinary Neuroanatomy and Clinical Neurology. $3^{\text {th }}$ d ed. St. Lous: Saunders Elsevier, 2009, p. 476-486.

DEWEY, C. W. Encephalopathy, vascular. In: CÔTÉ, E. Clinical veterinary advisor. $2^{\text {nd }}$ ed. St. Louis, Missouri: Elsevier Mosby, 2011, p. 345-346.

GAROSI, L.; McCONNELL, J. E.; PLATT, S. R.; BARONE, G.; BARON, J. C.; DE LAHUNTA, A.; SCHATZBERG, S. J. Results of diagnostic investigations and long-term outcome of $33 \mathrm{dogs}$ with brain infarction (2000-2004). Journal of Veterinary Internal Medicine, v. 19, n. 5, p. 725-731, 2005.

GAROSI, L. Cerebrovascular accidents. In: PLATT, S.; GAROSI, L. Small animal neurological emergencies. London, Manson Publishing, 2012. p. 319-332.

Cerebrovascular disease in dogs and cats.

Veterinary Clinics of North America Small Animal Practice, v. 40, n. 1, p. 65-79, 2010.

GAROSI, L.; McCONNELL, J. E. Ischemic stroke in dogs and humans: a comparative review. Journal of Small Animal Practice, v. 46, n. 11, p. 521-529, 2005. 
GAROSI, L. S.; PLATT, S. R. Treatment of veterinary internal medicine diseases of the dog and cat. cerebrovascular disease. In: BONAGURA, J. D.; $7^{\text {th }}$ ed. St. Louis, Missouri: Saunders Elsevier, 2010, p. TWEDT, D. C. Kirk's current veterinary therapy XIV. $14^{\text {th }}$ ed. St. Louis, Missouri: Saunders Elsevier, 2009. p. 1074-1077.

O'BRIEN, D. P.; COATES, J. R. Brain disease. In: ETTINGER, S. P.; FELDMAN, E. C. Textbook of 1413-1446.

WILLIAMS, K. J.; SUMMERS, B. A.; De LAHUNTA, A. Cerebrospinal cuterebriasis in cats and its association with feline ischemic encephalopathy. Veterinary Pathology, v. 35, n. 5, p. 330-343, 1998. 